\title{
KORELACIJA SUBJEKTIVNOG I OBJEKTIVNOG UPRAVNOG SPORA
}

Mr. sc. Inga Vezmar Barlek*

\author{
UDK 35.077.2(497.5) \\ https://doi.org/10.30925/zpfsr.42.2.14 \\ Ur.: 4. ožujka 2021. \\ Pr.: 1. lipnja 2021. \\ Stručni rad
}

\begin{abstract}
Sažetak
$U$ radu se analizom pregledane sudske prakse izlaže o uzajamnosti ${ }^{l} i$ povezanosti subjektivnog i objektivnog upravnog spora. Iako se ciljevi tih dvaju upravnih sporova razlikuju, sudska praksa dokazuje da su nedvojbeno povezani i međusobno ovisni. Upućuje se na važnost prepoznavanja različitosti mjerodavnih prigovora u jednom i drugom sporu te se upozorava na pravne posljedice ukidanja općeg akta u odnosu na konkretne subjektivne situacije. Nastoji se istaknuti uloga sudova svih vrsta da u postupcima koji se pred njima vode, kod sumnje na zakonitost općeg akta koji trebaju primijeniti, podnesu zahtjev Visokom upravnom sudu Republike Hrvatske za ocjenu zakonitosti tog akta.
\end{abstract}

Ključne riječi: subjektivni spor; objektivni spor; cilj spora; različitost; uzajamnost.

\section{1. $U V O D$}

Cilj je Zakona o upravnim sporovima (dalje: ZUS) ${ }^{2}$ osigurati objektivnu zakonitost i sudsku zaštitu prava i pravnih interesa fizičkih pravnih osoba i drugih stranaka. Predmet je subjektivnog upravnog spora određen čl. 3. st. 1. ZUS-a, dok je predmet objektivnog spora određen kao ocjena zakonitosti općeg akta jedinice

* Mr. sc. Inga Vezmar Barlek, sutkinja Visokog upravnog suda Republike Hrvatske; Inga. Vezmar@vusrh.pravosudje.hr. ORCID: https://orcid.org/0000-0003-1313-2849.

1 Korelacija (lat. correlatio: suodnos), značenje: 1. Odnos između dvaju relata (veličina - vektora, promjenljivih pojava i svojstava itd.), kod kojega jedan relat pokazuje pravilnu suvislost $\mathrm{s}$ drugim (ta suvislost ne mora biti uzročna zavisnost). 2. U filozofiji, međusobni odnos dvaju članova relacije... koji se nazivaju relati. Korelacija se razlikuje od odnosa po tome što relati stoje u odnosu uzajamnosti. 3. U biologiji, uzajamna ovisnost i međusobna povezanost stanica ili organa nekog organizma; zbog promjena jednog organa mijenja se do neke mjere i drugi organ. 4. U statistici, ovisnost između statističkih varijabla. Hrvatska enciklopedija, Leksikografski zavod Miroslav Krleža, pristup 23. prosinca 2020., https://www.enciklopedija. hr/natuknica.aspx?ID=33163

2 Zakon o upravnim sporovima, Narodne novine, br. 20/10., 143/12., 152/14., 94/16. - odluka Ustavnog suda RH i 29/17. 
lokalne i područne (regionalne) samouprave, pravne osobe koja ima javnu ovlast $\mathrm{i}$ pravne osobe koja obavlja javnu službu (dalje: opći akt). ${ }^{3}$

Na razlikovanje subjektivnog i objektivnog upravnog spora upozorava se i u znanstvenoj literaturi, pri čemu se koriste dva kriterija. Prvi: prvotni je cilj objektivnog spora zaštita objektivne zakonitosti, dok je prvotna svrha subjektivnog spora zaštita subjektivnih prava pojedinaca. Drugi je kriterij vrsta akta koji može biti predmet spora. Objektivni upravni spor bio bi onaj koji se može pokrenuti protiv općih akata, dok se pod subjektivnim razumiju sporovi koji se vode protiv upravnih akata. ${ }^{4}$

Već iz općih odredbi ZUS-a proizlazi ispreplitanje subjektivne i objektivne zakonitosti koju trebaju osigurati upravni sudovi i Visoki upravni sud Republike Hrvatske, ${ }^{5}$ pa će se u nastavku rada analizom sudske prakse nastojati prikazati suodnos subjektivne i objektivne zakonitosti u konkretnim slučajevima. Rad, stoga može poslužiti kao osnova za buduću znanstvenu obradu toga pitanja, s obzirom na to da ono sa znanstvenog aspekta do sada nije pobliže obrađeno, premda opravdano Ljubanović i Britvić Vetma upozoravaju na činjenicu da se čisti subjektivni spor ne može zamisliti bez objektivnog spora. ${ }^{6}$

Praktična važnost podjele sporova na subjektivne i objektivne prema vrsti akata može se promatrati u svjetlu učinka sudske odluke donesene u pojedinom sporu. Pritom se onemogućavanjem primjene općeg akta, osim objektivne zakonitosti, štite i sva subjektivna prava. ${ }^{7}$

Bitno je naglasiti kako ocjena objektivne zakonitosti općeg akta ne utječe samo na subjektivni upravni spor (i posljedično tomu postupke koji se vode pred javnopravnim tijelima), nego i na postupke koji se vode pred drugim sudovima, budući da i ti sudovi u sklopu svoje nadležnosti primjenjuju opće akte.

\section{PREDMET UPRAVNOG SPORA}

Premda u subjektivnom upravnom sporu stranke uvijek nastoje ostvariti zaštitu svojih konkretnih prava i pravnih interesa, nedvojbeno iz odredbe čl. 2. st. 1. ZUS-a ${ }^{8}$ proizlazi kako upravni sudovi u upravnom sporu ne pružaju samo zaštitu subjektivnih prava nego trebaju osigurati i objektivnu zakonitost. Dakle, osim što u konkretnom sporu upravni sudovi moraju imati na umu subjektivne pozicije stranke / stranaka i njihova traženja, ${ }^{9}$ moraju osigurati i suglasnost, npr. osporene pojedinačne odluke (ako

3 Čl. 3. stavak 2. ZUS-a.

4 Ljubanović, Boris i Bosiljka Britvić Vetma, „Vrste upravnih sporova“, Hrvatska i komparativna javna uprava: časopis za teoriju i praksu javne uprave 11, br. 3 (2011): 764.

5 Dalje: Visoki upravni sud.

6 Ljubanović, Britvić Vetma, Vrste upravnih sporova, 765.

7 Ljubanović, Britvić Vetma, Vrste upravnih sporova, 765.

8 Cilj je ovoga Zakona osigurati zakonitost i sudsku zaštitu prava i pravnih interesa fizičkih i pravnih osoba i drugih stranaka povrijeđenih pojedinačnim odlukama ili postupanjem javnopravnih tijela. Čl. 2. st. 1. ZUS-a.

9 Upravne stvari mogu biti jednostranačke ili dvostranačke pa tako u upravnom sporu uz tužitelja i tuženika (javnopravno tijelo iz čl. 18. ZUS-a) može sudjelovati i zainteresirana osoba (čl. 19. ZUS-a). 
je predmet spora ocjena zakonitosti pojedinačne odluke) s mjerodavnim materijalnim zakonom te provjeriti je li donesena u zakonom propisanom postupku. Ovo posljednje posebice zbog ispunjavanja uloge upravnih sudova u nadzoru zakonitosti rada uprave, kako bi se spriječilo nezakonito zadiranje autoriteta javne vlasti u prava i pravne interese građana.

S druge strane, u objektivnom upravnom sporu ispituje se objektivna zakonitost, odnosno suglasnost općeg akta s mjerodavnim zakonom ili statutom donositelja akta. ${ }^{10}$ To ne znači da se i u tom sporu ne promatra subjektivna pozicija podnositelja zahtjeva, budući da kod pokretanja postupka ocjene zakonitosti općeg akta na zahtjev, podnositelj zahtjeva mora dokazati da je pojedinačnom odlukom javnopravnog tijela, koja se temelji na općem aktu, došlo do povrede njegova prava ili pravnog interesa. ${ }^{11}$

Za razliku od toga, u objektivnom sporu koji je Visoki upravni sud ovlašten pokrenuti po službenoj dužnosti, subjektivni položaj adresata općeg akta imati će slabiju ulogu. ${ }^{12}$

I u znanstvenoj se literaturi navodi kako je detaljnim proučavanjem regulacije upravnog spora uočeno da je i u objektivnom sporu zastupljena subjektivna koncepcija spora. To nije moguće utvrditi u odnosu na kriterij akta, jer se ispituje opći akt, ali kriterij cilja vodi se s drukčijim zaključcima. Podnositelju zahtjeva koji osporava zakonitost općeg akta jer mu je pojedinačnom odlukom, donesenom na temelju općeg akta, povrijeđeno neko pravo ili pravni interes, primarni je cilj zaštititi svoja subjektivna prava i interese te se objektivni spor pokreće kako bi se nezakonita pojedinačna odluka stavila izvan snage. ${ }^{13}$

$\mathrm{Za}$ razumijevanje suodnosa ovih sporova, osim znanstvenog proučavanja i prakse Visokog upravnog suda kao primarno nadležnog u objektivnom upravnom sporu, bitna su i brojna stajališta Ustavnog suda Republike Hrvatske, ${ }^{14}$ izražena u odlukama koje donosi u postupcima koji se pred njim vode u odnosu na odluke Visokog upravnog suda donesene u objektivnom upravnom sporu. Iako je prilikom donošenja novoga ZUS-a i uvođenja u hrvatski pravni poredak objektivnog upravnog spora u nadležnosti Visokog upravnog suda, u stručnoj literaturi problematizirana nadležnost Ustavnog suda $\mathrm{u}$ odnosu na odluke koje Visoki upravni sud donosi $\mathrm{u}$ objektivnom sporu te je upozoreno na važnost međusudske suradnje, ${ }^{15}$ sada je nedvojbeno da je Ustavni sud prihvatio kontrolu odluka Visokog upravnog suda donesenih u objektivnom upravnom sporu.

Tako vezano na cilj i predmet objektivnog upravnog spora, Ustavni sud navodi: „....Iz navedenih odredbi ZUS-a razvidno je da Visoki upravni sud može u dva

10 Prema čl. 86. st. 3. ZUS-a, Sud će presudom ukinuti opći akt ili pojedine njegove odredbe, ako utvrdi da nije suglasan sa zakonom ili statutom javnopravnog tijela.

11 Čl. 83. st. 1. i čl. 84. st. 2. ZUS-a.

12 Čl. 83. st. 2. ZUS-a.

13 Crnković, Mateja, „Koncepcije o prirodi upravnog spora u hrvatskom i poredbenom pravu“, Zbornik Pravnog fakulteta u Zagrebu 65, br. 5 (2015): 715.

14 Dalje: Ustavni sud.

15 Omejec, Jasna i Slavica, Banić, „Diferencijacija propisa i općih akata u budućoj praksi Ustavnog suda i upravnog suda u povodu Zakona o upravnim sporovima (2010.)“, Zbornik radova Pravnog fakulteta u Splitu 49, br. 2 (2012): 320-322. 
slučaja odlučivati o zakonitosti općih akata:

- na zahtjev fizičke ili pravne osobe ili skupine osoba povezanih zajedničkim interesom ako je pojedinačnom odlukom javnopravnog tijela koja se temelji na općem aktu došlo do povrede njihova prava ili pravnog interesa $\mathrm{i}$

- kada sam utvrdi da je određeni opći akt nezakonit (postupanje ex offo).

U prvom slučaju postupak ocjene zakonitosti nekog općeg akta provodi se radi zaštite prava ili pravnog interesa fizičke ili pravne osobe ili skupine osoba povezanih zajedničkim interesom koje su zahtjev podnijele. Visoki upravni sud u takvom postupku posredno odlučuje o pojedinačnim pravima, obvezama i pravnim interesima te donosi presude i rješenja, dakle pojedinačne akte. Stoga se i protiv tih presuda i rješenja, nakon njihove pravomoćnosti, može podnijeti ustavna tužba.

U drugom slučaju cilj postupka jest (samo) zaštita objektivnog pravnog poretka. I u tom slučaju presude iz tog postupka se mogu osporavati ustavnom tužbom.

Ustavni sud utvrđuje da se podnošenjem ustavne tužbe, objektivni upravni spor vođen pred Visokim upravnim sudom transformira (postaje) u postupak za zaštitu ustavnih prava pred Ustavnim sudom. ${ }^{\text {" } 16}$

\section{NEDOPUŠTENI PRIGOVORI STRANAKA OVISNO O PREDMETU SPORA}

Iz dosada rečenog, proizlazi nedvojbena povezanost oba upravna spora. Stoga se u praksi primjećuje kako stranke u jednom ili drugom sporu iznose prigovore koji, bez obzira na uzajamnu povezanost jednoga i drugog spora, u pojedinom sporu nisu dopušteni, jer izlaze izvan okvira dopuštenog ispitivanja zakonitosti osporene odluke koje je određeno predmetom upravnog spora i nadležnošću prvostupanjskog upravnog odnosno Visokog upravnog suda (kao prvostupanjskog suda ili žalbenog suda odnosno suda koji ocjenjuje zakonitost općeg akta). ${ }^{17}$

Tako u sporovima koji se vode radi ocjene zakonitosti općeg akta stranke često iznose prigovore o nezakonitosti pojedinačne odluke koja je donesena na temelju općeg akta. Takve prigovore, međutim treba iznositi u subjektivnom upravnom (ili nekom drugom) sporu u kojem se osporava pojedinačna odluka. Taj spor ni upravni sudovi ni Visoki upravni sud nisu ovlašteni pokrenuti po službenoj dužnosti nego je to u isključivoj dispoziciji stranke koje se tiče pojedinačna odluka.

Tako primjerice u sporu u kojem je bila sporna zakonitost Odluke o postavljanju reklamnih panoa, ${ }^{18}$ stranka je iznosila prigovor da se na temelju te Odluke naplaćuje naknada za reklame postavljene na zemljištu koje nije vlasništvo jedinice lokalne samouprave. Ocjenjujući zakonitost sporne Odluke, Sud je utvrdio kako njome nije propisana takva mogućnost, što znači da ostaje sporno pitanje zakonitosti njezine primjene.

U tom je smislu Visoki upravni sud zauzeo stajalište kako način primjene općeg

16 Ustavni sud, U-III-4035/2013 i U-III-2272/2015 od 26. siječnja 2016.

17 Čl. 12. st. 2. i 3. ZUS-a.

18 Službeni glasnik Grada Nina, br. 29/07. i 4/09. 
akta ne utječe na njegovu objektivnu zakonitost. ${ }^{19}$ Dakle, moguća je situacija u kojoj je opći akt zakonit u objektivnom smislu (donesen u suglasnosti s mjerodavnim zakonom i statutom), no nezakonito se primjenjuje, što će dovesti do nezakonitosti pojedinačne odluke koja je utemeljena na općem aktu.

Ovaj je problem prepoznat i sa znanstvenog stajališta, ${ }^{20}$ pa Crnković razmišlja kako bi, ako se subjektivna i objektivna koncepcija ne bi promatrale tako da jedna isključuje drugu nego da se nadopunjuju, trebalo omogućiti Visokom upravnom sudu da, ako smatra nužnim, u postupku ocjene zakonitosti općeg akta ispita i zakonitost pojedinačne odluke utemeljene na tom općem aktu. To potkrepljuje činjenica da ne postoji akademski ,čisti model“ ni subjektivnog ni objektivnog upravnog spora te je nužno uzeti u obzir obje koncepcije. ${ }^{21}$

S druge strane, u sporu o zakonitosti pojedinačne odluke (subjektivnom upravnom sporu) nalazimo prigovore kojima se osporava zakonitost općeg akta na temelju kojeg je donesena pojedinačna odluka.

Tako primjerice u sporu o zakonitosti rješenja o utvrđivanju obveze plaćanja komunalnoga doprinosa, tužitelj je iznosio prigovore o pogrešnom određivanju zona naselja u Odluci o komunalnom doprinosu jedinice lokalne samouprave, na temelju koje je komunalni doprinos određen. ${ }^{22}$ Ti se prigovori mogu ispitati samo u objektivnom upravnom sporu, u vezi s čim stranka i nadležni sud (ako te prigovore nalazi osnovanima) imaju mogućnost pred Visokim upravnim sudom pokrenuti postupak za ocjenu zakonitosti općeg akta. Ako je riječ o sporu koji se vodi pred Visokim upravnim sudom, taj sud može pokrenuti postupak po službenoj dužnosti, o čemu će više riječi biti u nastavku rada.

\section{PRAVNE POSLJEDICE UKIDANJA OPĆEG AKTA ERGA OMNES}

Nužno je naglasiti kako je pravomoćna presuda, kojom se odlučuje o zakonitosti općeg akta, obvezna za sve. ${ }^{23} \mathrm{U}$ vezi s tim u teoriji se ističe da su objektivni sporovi učinkovitiji od subjektivnih jer se s pomoću objektivnog upravnog spora ostvaruje šira zaštita prava građana i obuhvatnija zakonitost. U sporu o objektivnoj zakonitosti štite se i sva subjektivna prava koja su nastala iz odnosa koji su uređeni općim aktom. ${ }^{24}$

Pravne posljedice ukidanja općeg akta u odnosu na podnositelja zahtjeva za ocjenu zakonitosti i već donesene pojedinačne odluke o njegovom pravu ili pravnom interesu, propisane su ZUS-om. Podnositelj zahtjeva ima pravo podnijeti zahtjev nadležnom javnopravnom tijelu za izmjenu pojedinačne odluke kojom je povrijeđeno njegovo pravo ili pravni interes odgovarajućom primjenom odredaba o obnovi upravnog postupka u roku od tri mjeseca od dana objave presude u Narodnim

19 Visoki upravni sud, Usoz-341/13-7 od 26. studenoga 2014.

20 Crnković, Koncepcije o prirodi upravnog spora u hrvatskom i poredbenom pravu, 715.

21 Crnković, Koncepcije o prirodi upravnog spora u hrvatskom i poredbenom pravu, 718.

22 Visoki upravni sud, Usž-2490/19-2 od 10. prosinca 2020.

23 Čl. 10. st. 2. ZUS-a.

24 Ljubanović, Britvić Vetma, Vrste upravnih sporova, 765. 
novinama. Pravnim subjektima koji nisu podnijeli zahtjev za ocjenu zakonitosti općeg akta, iako su im konkretnim odlukama povrijeđena prava ili pravni interesi, uskraćena je mogućnost izmjene pravomoćnih pojedinačnih odluka s pravnim djelovanjem $e x$ tunc. ${ }^{25}$

Dakle, ZUS uređujući specifično posljedice ukidanja općeg akta, primarno polazi od objektivnog spora koji se pokreće na zahtjev, pritom slijedeći koncepciju prema kojoj je polazište takva objektivnog spora subjektivni položaj podnositelja zahtjeva (povreda prava ili pravnih interesa konkretnom pojedinačnom odlukom). S tim u vezi opravdana je kritika kako je zakonodavac takvim uređenjem mogućnost ocjene zakonitosti općih akata nepotrebno suzio, budući da je reagiranje građana na nezakonite opće akte predviđeno ponajprije kada je već nastupila povreda njihovih prava ili pravnih interesa. Time je zakonodavac propustio ZUS-om ustrojiti sustav kojim bi se osiguralo pravodobno sprječavanje svih pravnih posljedica koje mogu nastati nezakonitim općim aktima. ${ }^{26}$ Navedeni nedostatak pokušava se otkloniti u praksi Visokog upravnog suda tako da sud maksimalno koristi ovlast pokretanja postupka ocjene zakonitosti općeg akta po službenoj dužnosti. ${ }^{27}$

Prema stajalištu Visokog upravnog suda, odredba ZUS-a o otklanjanju pravnih posljedica koje je proizveo nezakoniti opći akt mora se primijeniti i u odnosu na druge podnositelje zahtjeva o čijim je zahtjevima u odnosu na isti ukinuti akt riješeno $u$ kasnijim sporovima, nakon što je sporni opći akt već ukinut. ${ }^{28}$ Naime, daljnji postupci u odnosu na isti ukinuti opći akt bit će obustavljeni, budući da Sud nema pravne mogućnosti ocijeniti zakonitost akta koji je prestao vrijediti.

Presuda donesena u objektivnom upravnom sporu nužno će se odraziti i na sve druge postupke koji se vode o subjektivnim pravima građana pred svim sudovima (i javnopravnim tijelima), a koji nisu pravomoćno dovršeni i za donošenje odluke u kojima je mjerodavan ukinuti opći akt. Naime, ne samo upravni sudovi nego i drugi sudovi u sklopu svoje nadležnosti, donose odluke na temelju općih akata čija ocjena zakonitosti može biti predmetom objektivnog upravnog spora.

Budući da pravne posljedice ukidanja općeg akta u odnosu na pendentne postupke nisu zakonom razrađene (osim izričite odredbe ZUS-a kako je takva presuda obvezna za sve), za sagledavanje toga pravnog pitanja treba upozoriti na stajališta Ustavnog suda.

Tako je Ustavni sud ukinuo presude Županijskog suda u Dubrovniku i Općinskog suda u Dubrovniku, koji nisu na odgovarajući način uzeli u obzir činjenicu da je Visoki upravni sud tijekom postupka koji se vodio pred tim sudovima ukinuo opći akt mjerodavan za donošenje odluke u konkretnom slučaju. Dakle, opći je akt bio ukinut prije nego što su navedeni sudovi donijeli svoje odluke.

25 Čl. 87. ZUS-a. Čl. 123. do 127. Zakona o općem upravnom postupku, Narodne novine, br. 47/09. Šikić, Marko i Dario Đerđa, Komentar Zakona o upravnim sporovima (Zagreb: Novi informator, 2012.), 312.

26 Čl. 84. st. 2. ZUS-a. Šikić i Đerđa, Komentar Zakona o upravnim sporovima, 304.

27 Čl. 83. st. 2. ZUS-a. Prema podatcima pisarnice Visokog upravnog suda u 2020. riješeno je 92 predmeta ocjene zakonitosti općih akata, od čega je prema podatcima Vijeća za ocjenu zakonitosti općih akata oko 57 \% pokrenuto po službenoj dužnosti.

28 Visoki upravni sud, Usoz-134/15 od 30. studenoga 2015. 
Ustavni sud navodi: „Stavak 5. članka 58. Ustavnog zakona odnosi se upravo na konkretan slučaj podnositelja. Naime, riječ je o postupku u kojem o pravnoj stvari, do dana objave presude Visokog upravnog suda kojom se ukida sporni propis, nije pravomoćno odlučeno, a taj se propis neposredno primjenjuje u toj pravnoj stvari. Iz stavka 5. proizlazi da se takav ukinuti propis neće primjenjivati "od dana stupanja na snagu odluke Ustavnog suda", odnosno od dana objave presude Visokog upravnog suda kojom je propis ukinut (isto proizlazi i iz odredbe stavka 2. članka 55. Ustavnog zakona, koja propisuje da "ukinuti... drugi propis... prestaje važiti danom objave odluke Ustavnog suda u 'Narodnim novinama'")....Ustavni sud ocjenjuje da je i odluka u predmetu broj: U-III-5708/2010 također mjerodavna u konkretnom slučaju. U njoj je izneseno stajalište da "ukinuti zakon i drugi propis ... prestaju važiti danom objave odluke Ustavnog suda u 'Narodnim novinama'". Prema tome, odluke Ustavnog suda imaju učinak samo za ubuduće (pro futuro), što bi u konkretnom slučaju značilo da sve sudske odluke donesene nakon objave presude Visokog upravnog suda kojom se ukida osporeni propis, nisu valjane.“ ${ }^{29}$

Također, Ustavni sud ističe: „Uzimajući u obzir ova ranije izražena stajališta Ustavnog suda, a imajući pritom na umu odredbu stavka 5. članka 58. Ustavnog zakona, proizlazi da odluke Ustavnog suda imaju učinak pro futuro, što bi u konkretnom slučaju značilo da sudske odluke koje bi bile utemeljene na ukinutom propisu, a donesene nakon njegova ukidanja (nakon objave presude Visokog upravnog suda kojom se ukida osporeni propis), ne bi bile valjane." Ovakvo stajalište Ustavni je sud zauzeo u predmetu broj: U-III-1673/2015 od 25. svibnja 2017. i time otklonio sve postojeće nedoumice i razilaženja u sudskoj praksi. ${ }^{30}$

Međutim, u upravnim stvarima izdavanja akata za provedbu prostornih planova, Ustavni sud je stajališta „da je obveza upravnih tijela primijeniti dokumente prostornog uređenja važeće u trenutku podnošenja zahtjeva za izdavanje upravnog akta“, bez obzira na to što je mjerodavni opći akt ukinut nakon podnošenja zahtjeva za izdavanje upravnog akta. Stoga je u konkretnom slučaju Ustavni sud ukinuo presudu Visokog upravnog suda, kojom je, budući da je tijekom trajanja žalbenog spora opći akt bio ukinut, bila poništena prvostupanjska presuda i rješenja javnopravnih tijela (kojima je u konačnici zainteresiranoj osobi bila izdana građevinska dozvola na temelju prostornog plana koji je ukinut kasnijom presudom Visokog upravnog suda). ${ }^{31}$

Nužno je istaknuti i da je Visoki upravni sud stajališta kako je ovlašten ponovno ocjenjivati zakonitost općeg akta (odnosno pojedine odredbe) koji je u prethodnom sporu našao zakonitim, dok međutim ukidanjem općeg akta (odnosno njegove odredbe) prestaju postojati pretpostavke za ponovnu ocjenu zakonitosti istog općeg akta (pojedine odredbe). ${ }^{32}$ Naime, ako Sud u povodu konkretnih prigovora u ranijem sporu ocjeni opći akt zakonitim, u povodu novog zahtjeva ili obavijesti građana i u kontekstu novih / drugih prigovora, može izmijeniti svoju ocjenu i doći do zaključka da je opći akt nezakonit. Za razliku od toga kada je opći akt jednom ocijenjen

29 Ustavni sud, U-III-1673/2015 od 25. svibnja 2017.

30 Ustavni sud, U-III-2522/2017 od 21. rujna 2017.

31 Ustavni sud, U-III-4397/2018 od 29. travnja 2021.

32 Visoki upravni sud, Usoz-6/14-3 od 22. prosinca 2014. 
nezakonitim i kao posljedica toga ukinut, njegova se zakonitost ne može ponovo ocjenjivati.

\section{POSTUPANJA SUDOVA U VEZI SA ZAKONITOSTI OPĆEG AKTA MJERODAVNOG U KONKRETNOM SPORU}

U nastavku rada analizirat će se postupanje sudova u konkretnim predmetima u kojima je trebalo primijeniti određeni opći akt, ali je uočena njegova nezakonitost (odnosno nezakonitost pojedinih odredbi općeg akta) ili je opći akt ukinut tijekom vođenja konkretnoga spora te će se iznijeti stajališta Ustavnog suda ako nadležni sud propusti reagirati na nezakonitost općeg akta koju je uočio.

\subsection{Postupanje Visokog upravnog suda}

U konkretnom žalbenom sporu protiv prvostupanjske presude Visoki upravni sud je uočio kako je mjerodavni opći akt (Pravilnik o mjerilima za izračun naknade za korištenje DTK-e u vlasništvu Općine Dugopolje i o mjerilima za izračun naknade za korištenje zemljišta, javnih površina i nerazvrstanih cesta koje su vlasništvo Općine Dugopolje i nad kojima upravlja Općina Dugopolje u svrhu polaganja DTK ${ }^{33}$ ) nezakonit, jer donositelj akta (Općinsko vijeće) za donošenje tog akta nije imao zakonske osnove. Stoga je po službenoj dužnosti pokrenuo postupak ocjene zakonitosti općeg akta i nakon provedenoga postupka ga je ukinuo. ${ }^{34}$ Opći je akt prestao vrijediti danom objave presude Visokog upravnog suda u Narodnim novinama, ${ }^{35}$ nakon čega je dovršen žalbeni spor, poništena prvostupanjska presuda kao i rješenja javnopravnih tijela donesena na temelju ukinutog općeg akta. ${ }^{36} \mathrm{U}$ daljnjim prvostupanjskim sporovima u kojima je primjenom ukinutog akta upravni sud trebao ocijeniti zakonitost pojedinačnih odluka, prvostupanjski je sud uzeo u obzir činjenicu da je presudom Visokog upravnog suda, ukinut mjerodavni opći akt. ${ }^{37}$

U drugom predmetu, također odlučujući o žalbi protiv presude prvostupanjskog upravnog suda, Visoki upravni sud posumnjao je u zakonitost odredbe općeg akta koji je trebao primijeniti (čl. 192. Odluke o izmjenama i dopunama Prostornog plana Osječko-baranjske županije). ${ }^{38}$ Stoga je pokrenuo postupak ocjene zakonitosti općeg akta po službenoj dužnosti, međutim nakon provedenog postupka u kojem su pribavljena i očitovanja mjerodavnih ministarstava, nije našao nezakonitosti sporne odredbe te je žalbeni spor dovršio njezinom primjenom..$^{39}$

Za razliku od navedenih predmeta u kojima se zakonitost općeg akta pokazala dvojbenom u trenutku rješavanja žalbe, nalazimo i predmete u kojima Visoki upravni sud treba riješiti žalbeni predmet nakon što je već ukinuo opći akt. U tim je slučajevima

33 Službeni vjesnik Općine Dugopolje, br. 5/11.

34 Visoki upravni sud, Usoz-95/16-3 od 28. listopada 2016., Narodne novine, br. 109/16.

35 Čl. 86. st. 4. ZUS-a.

36 Visoki upravni sud, Usž-1523/16-4 od 8. prosinca 2016.

37 Visoki upravni sud, Usž-4740/18-2 od 18. travnja 2019.

38 Županijski glasnik, br. $4 / 10$.

39 Visoki upravni sud, Usž-1179/15-2 od 27. travnja 2017. i Usoz-112/16-7 od 30. ožujka 2017. 
prvostupanjska presuda protiv koje je podnesena žalba o kojoj tek treba odlučiti, donesena prije ukidanja općeg akta te je (kao i pojedinačne odluke javnopravnih tijela) donesena na temelju njega.

Tako je u povodu obavijesti građana Visoki upravni sud ukinuo opći akt (Odluku o izmjeni i dopuni Odluke o komunalnom redu ${ }^{40}$ ), a nakon objave te presude u Narodnim novinama trebao je odlučiti o žalbi protiv presude prvostupanjskog upravnog suda koja je donesena na temelju općeg akta prije no što je ukinut. Polazeći od činjenice da je objavom presude u Narodnim novinama opći akt prestao vrijediti, izričite norme kako je ta presuda obvezna za sva naprijed navedena stajališta Ustavnog suda (o nevaljanosti sudskih odluka koje bi bile utemeljene na ukinutom općem aktu), odlučujući o žalbi, Visoki upravni sud poništio je prvostupanjsku presudu i rješenja javnopravnih tijela koja su donesena na temelju (kasnije) ukinutog općeg akta. ${ }^{41}$

\subsection{Postupanje upravnih i drugih sudova}

Niz je upravnih i drugih pravnih stvari u kojima sudovi rješavajući konkretan spor moraju primijeniti određeni opći akt. Radi navedenog, a ako sud koji treba primijeniti odgovarajući opći akt posumnja u njegovu zakonitost, ZUS-om je predviđena mogućnost da taj sud Visokom upravnom sudu podnese zahtjev za ocjenu zakonitosti općeg akta. ${ }^{42}$ Za podnošenje takvog zahtjeva, za razliku od slučaja kada zahtjev podnose fizičke ili pravne osobe, nije propisan rok.

U dosadašnjoj praksi Visokog upravnog suda zabilježeno je da su takve zahtjeve podnosili ne samo prvostupanjski upravni sudovi nego i županijski, trgovački i općinski sudovi, iako od 1. siječnja 2012. (od kada je objektivni upravni spor u nadležnosti Visokog upravnog suda) do kraja 2020., takvih zahtjeva u ukupnoj masi zahtjeva za ocjenu zakonitosti općih akata ima relativno malo. Prema podatcima pisarnice Visokog upravnog suda, u navedenom su razdoblju drugi sudovi (dakle ne upravni sudovi) podnijeli svega pet zahtjeva. Može se zaključiti kako u tom području svakako ima prostora za napredak te osvješćivanje i drugih sudova o objektivnom upravnom sporu.

Na mogućnost pokretanja postupka ocjene zakonitosti općeg akta drugih sudova upozoravaju i Šikić i Đerđa uz iznošenje pretpostavke da će sudovi takav zahtjev podnositi u pravilu onda kada konkretno trebaju primijeniti opći akt za koji smatraju da je u neskladu sa zakonom. Međutim, budući da nema nikakvih zakonskih ograničenja, svaki je sud ovlašten podnijeti zahtjev za ocjenu zakonitosti svakog općeg akta, pa i onoga koji se ne odnosi na stvari iz njegove nadležnosti. ${ }^{43}$

U odnosu na upravne sudove, valja reći kako ZUS propisuje mogućnost prekida upravnog spora u kojem se pojavi pitanje ocjene zakonitosti općeg akta. Prekid spora traje dok Visoki upravni sud ne odluči o zakonitosti općeg akta koji

40 Službeni glasnik Grada Dubrovnika, br. 8/19.

41 Visoki upravni sud, Usoz-77/19-11 od 29. lipnja 2020., Narodne novine, br. 98/20. i Usž2734/20-3 od 23. listopada 2020.

42 Čl. 83. st. 2. ZUS-a.

43 Šikić i Đerđa, Komentar Zakona o upravnim sporovima, 305. 
konkretno primjenjuje. ${ }^{44} \mathrm{U}$ nastavku će se rada prikazati nekoliko situacija u kojima su prvostupanjski upravni sudovi podnijeli zahtjev za ocjenu zakonitosti te postupanja tih sudova nakon što je Visoki upravni sud odlučio o zakonitosti općeg akta.

Odlučujući o zakonitosti pojedinačne odluke Upravni sud u Rijeci je smatrao nezakonitom određenu odredbu Odluke o novčanoj pomoći po rođenju djeteta ${ }^{45}$ te je prekinuo upravni spor i Visokom upravnom sudu podnio zahtjev za ocjenu zakonitosti sporne odredbe. Nakon što je presudom Visokog upravnog suda ukinuta sporna odredba, Upravni sud u Rijeci nastavio je subjektivni spor i presudom poništio osporenu pojedinačnu odluku. ${ }^{46}$

Istovjetno je Upravni sud u Rijeci postupio u predmetu koji je trebao presuditi na temelju Odluke o kriterijima za sufinanciranje smještaja djece u predškolskim ustanovama u ostalim gradovima i općinama Primorsko-goranske županije te obrtima za obavljanje djelatnosti predškolskog odgoja i obrtima s registriranom djelatnošću dadilje na području Primorsko-goranske županije. ${ }^{47}$ Po uočenoj nezakonitosti navedene Odluke, prvostupanjski spor je prekinut, podnesen zahtjev Visokom upravnom sudu za ocjenu zakonitosti općeg akta, a nakon objave presude Visokog upravnog suda, kojom je ukinut opći akt u Narodnim novinama, poništene su osporene pojedinačne odluke. $^{48}$

Nešto je drukčija situacija bila u predmetu u kojem je također Upravni sud u Rijeci podnio zahtjev za ocjenu zakonitosti određenih odredbi Odluke o komunalnom doprinosu Grada Crikvenice. ${ }^{49}$ No, prije podnošenja zahtjeva suda, zahtjev je Visokom upravnom sudu već podnijela jedna pravna osoba, tako da je Visoki upravni sud u povodu zahtjeva te osobe ukinuo određene odredbe odluke. Posljedica je toga bila da u povodu kasnijega zahtjeva Upravnog suda više nije bilo uvjeta za ocjenu zakonitosti. Upravni sud u Rijeci subjektivni je spor presudio uzevši u obzir da su pojedine odredbe odluke ukinute te da su prestale vrijediti od objave te presude u Narodnim novinama. ${ }^{50}$

Zanimljiva je situacija u kojoj je Upravni sud u Zagrebu nakon prekida upravnog spora, Visokom upravnom sudu podnio zahtjev za ocjenu zakonitosti određene odredbe Pravila o uravnoteženju elektroenergetskog sustava, ${ }^{51}$ koja su u međuvremenu prestala vrijediti. S obzirom na tu činjenicu, Visoki upravni sud nije imao pravne mogućnosti ocijeniti njihovu zakonitost, jer nije bilo niti ima mogućnosti ocijeniti zakonitost akta koji više ne vrijedi. No, takav akt, unatoč prestanku važenja, može biti mjerodavan za dovršetak konkretnoga subjektivnog upravnog spora. To znači da ga prvostupanjski

44 Čl. 45. st. 2. točka 2. ZUS-a.

45 Službene novine Primorsko-goranske županije, br. 28/12. i 36/12.

46 Visoki upravni sud; Usoz-294/13-7 od 27. travnja 2015.; Upravni sud u Rijeci, UsI-1823/12-8 od 30. travnja 2013. i UsI-737/15-12 od 30. lipnja 2015.

47 Službene novine Primorsko-goranske županije, br. 13/16.

48 Visoki upravni sud, Usoz-44/18-4 od 29. studenoga 2018., Narodne novine, br. 120/18., Upravni sud u Rijeci, UsI-1512/17 od 29. lipnja 2018. i UsI-40/19-9 od 8. siječnja 2019.

49 Službene novine Primorsko-goranske županije, br. 45/09. 11/11., 14/11. i 17/13.

50 Visoki upravni sud, Usoz-10/17-5 od 30. svibnja 2017., Narodne novine, br. 71/17.; Usoz63/17-5 od 26. rujna 2017.; Upravni sud u Rijeci, UsI-1416/15-6 od 10. svibnja 2017. i UsI1543/17-3 od 20. prosinca 2017.

51 Narodne novine, br. 133/06. i 135/11. 
sud treba primijeniti, odnosno ovisno o okolnostima konkretnoga slučaja i prijelaznim odredbama novog akta, ocijeniti ima li uvjeta za primjenu općeg akta koji je prestao vrijediti. $^{52}$

\subsection{Propust nadležnog suda na pokretanje postupka ocjene zakonitosti općeg akta}

Uočene su situacije u kojima sudovi propuštaju podnijeti zahtjev za ocjenu zakonitosti općeg akta koji je mjerodavan za rješavanje konkretnog spora, premda iz obrazloženja njihove odluke proizlazi da akt nalaze nezakonitim. Nailazimo i na situacije u kojima propuštaju takav zahtjev (koji je podnijela fizička ili pravna osoba) ustupiti Visokom upravnom sudu kao nadležnom za vođenje objektivnog upravnog spora. Taj je propust za podnositelja zahtjeva pravnoodlučan budući da je podnošenje zahtjeva građana vezano za prekluzivni rok.

U odnosu na propuštanje nadležnoga suda da podnese Visokom upravnom sudu zahtjev za ocjenu zakonitosti, važna je odluka Ustavnog suda donesena u slučaju propusta Prekršajnog suda u Crikvenici da podnese zahtjev za ocjenu zakonitosti određene odredbe Odluke o zabrani i ograničenju građevinskih radova za vrijeme turističke sezone Grada Crikvenice, ${ }^{53}$ a za koju, iz obrazloženja presude Prekršajnog suda, proizlazi da nije u skladu sa zakonom.

Ustavni sud ,utvrđuje da Prekršajni sud nije postupio prema članku 37. stavku 2. Ustavnog zakona iako u presudi navodi da se nesuglasnost sa zakonom Odluke koju primjenjuje "može ... utvrđivati putem Ustavnog suda".

...Nadalje, Prekršajni sud nije postupio ni prema članku 83. stavku 2. ZUS-a i podnio Visokom upravnom sudu zahtjev za pokretanje postupka ocjene zakonitosti Odluke na čiju očitu nesuglasnost sa Zakonom je podnositelj ukazivao.

Ustavni sud primjećuje da je Prekršajni sud donio osporenu presudu 19. listopada 2012.

ZUS, kojim je propisana nova nadležnost Visokog upravnog suda - ocjena zakonitosti općih akata, stupio je na snagu 1. siječnja 2012. Do stupanja na snagu ZUS-a u Republici Hrvatskoj nije postojalo sudsko tijelo nadležno za kontrolu zakonitosti općih akata tijela jedinica lokalne i područne (regionalne) samouprave i drugih pravnih osoba s javnim ovlastima. Zbog toga je Ustavni sud u svojoj dosadašnjoj praksi opće akte javnopravnih tijela podvodio pod određenje "drugog propisa" u smislu članka 125. alineje 2. Ustava...

...Takva promjena u nadležnosti za ocjenu zakonitosti općeg akta Prekršajnom sudu morala je biti poznata.

Kraj očitog nesklada Odluke sa Zakonom u pogledu osobe koja će se kazniti za prekršaj, na što je ukazivao podnositelj tijekom prekršajnog postupka, Prekršajni sud propustio je postupiti sukladno svojoj obvezi propisanoj Ustavnim zakonom odnosno ZUS-om.

Podnositelju se, prema mišljenju Ustavnog suda, ne može staviti na teret što

52 Visoki upravni sud, Usoz-70/16-2 od 24. siječnja 2017.; Upravni sud u Zagrebu, UsI-4457/13 od 8. lipnja 2016. i UsI- 467/17-20 od 24. svibnja 2017.

53 Službene novine Primorsko-goranske županije, br. 114/04. i 21/08. 
nije sam podnio prijedlog za ocjenu zakonitosti Odluke Ustavnom sudu. Naime, na nesuglasnost Odluke sa Zakonom ukazivao je tijekom prekršajnog postupka, a u vrijeme zaprimanja presude Prekršajnog suda "već" je bio nadležan Visoki upravni sud, kojemu se podnositelj i obratio...

...Propuštanjem Prekršajnog suda da postupi sukladno svojoj obvezi propisanoj Ustavnim zakonom odnosno ZUS-om, prema ocjeni Ustavnog suda, stvoren je negativni vanjski dojam da je podnositelj, kao investitor, prekršajno kažnjen za djelo za koje je trebao biti kažnjen izvođač radova...

...Sagledavajući sve okolnosti ovog slučaja, Ustavni sud utvrđuje da je podnositelju povrijeđeno ustavno pravo na pravično suđenje zajamčeno člankom 29. stavkom 1. Ustava“". 54

Iz svega dosada navedenog te citiranih stajališta Ustavnog suda proizlazi važnost svih sudova da prepoznaju nadležnost Visokog upravnog suda za suđenje u objektivnom upravnom sporu te da, ako sumnjaju u zakonitost općeg akta koji trebaju primijeniti, primijene čl. 83. st. 2. ZUS-a propisanu mogućnost i Visokom upravnom sudu podnesu zahtjev za ocjenu zakonitosti.

Uz to je važno uočiti i da upravni sudovi nemaju osnove odbaciti tužbu (sadržajno zahtjev za ocjenu zakonitosti općeg akta) na temelju u odredbe čl. 30. st. 1. toč. 7. ZUS-a, uz obrazloženje da je tužba podnesena u stvari koja ne može biti predmet upravnog spora, jer se radi o zahtjevu za ocjenu zakonitosti općeg akta. Ako nije riječ o tužbi nego o zahtjevu za ocjenu zakonitosti općeg akta, upravni sud takav zahtjev mora ustupiti Visokom upravnom sudu na nadležno odlučivanje ${ }^{55}$ jer se time osigurava pravodobnost zahtjeva. Činjenica što je podnesak kojim se spor pokreće eventualno nazvan tužba, iako je sadržajno riječ o zahtjevu za ocjenu zakonitosti općeg akta, ne može biti podnositelju zahtjeva na štetu te upozorava na pretjerani formalizam u postupanju prvostupanjskog suda koji bi odbacio takav podnesak.

Tako je, primjerice, odlučujući o žalbi stranke protiv rješenja Upravnog suda u Rijeci kojim je odbačena tužba (zapravo zahtjev za ocjenu zakonitosti općeg akta), Visoki upravni sud poništio rješenje prvostupanjskog suda i odlučio da je nadležan za ocjenu zakonitosti općeg akta. Nakon toga je zahtjev ispitan u objektivnom upravnom sporu te je ukinuta sporna Odluka o utvrđivanju statusa javnog dobra u općoj upotrebi - k.č.zgr. 115 i k.č.zgr. 116, obje k.o. Pula. ${ }^{56}$

\section{ZAKLJUČAK}

Iz iznesenih znanstvenih proučavanja, sudske prakse te stajališta Ustavnog i Visokog upravnog suda proizlazi nedvojbena povezanost subjektivnog i objektivnog upravnog spora, ali i povezanost postupaka koji se vode pred drugim sudovima u

54 Ustavni sud, U-III-6013/2012 od 1. prosinca 2014.

55 Čl. 28. st. 2. ZUS-a.

56 Visoki upravni sud, Uš̌-3545/18-3 od 19. prosinca 2019.; Usoz-22/20-6 od 21. prosinca 2020., Narodne novine, br. 10/21. i Upravni sud u Rijeci, UsI-1283/16-5 od 15. svibnja 2018. Tako i Visoki upravni sud, Usž-4103/19-2 od 12. veljače 2020; Upravni sud u Splitu, UsI-114/19-5. od 9. svibnja 2019.; Odluka o utvrđivanju statusa javnog dobra u općoj upotrebi - k.č.zgr. 115 i k.č.zgr. 116, obje k.o. Pula, Službene novine Grada Pule, broj 6/16. 
kojima se odlučuje o subjektivnim pravima, s objektivnim upravnim sporom.

Strankama u sporu važno je prepoznati različitost predmeta subjektivnog odnosno objektivnog spora (bez obzira na njihovu uzajamnu povezanost), kako bi pravilno mogle usmjeriti prigovore prema konkretnom predmetu osporavanja.

U odnosu na sudove (ne samo upravne) važno je prepoznati ulogu Visokog upravnog suda u objektivnom upravnom sporu, jer od objektivne zakonitosti općeg akta ovisi rješenje niza pojedinačnih situacija.

Nezakonit opći akt (ili pojedine njegove odredbe) ne može biti valjana osnova za donošenje zakonite pojedinačne odluke, bilo sudske, bilo odluke javnopravnog tijela. Stoga takav akt u zakonom predviđenom postupku treba staviti izvan snage. To je u cilju očuvanja objektivne zakonitosti pravnog poretka, ali time i osiguranja zakonitosti pojedinačnih akata kojima se odlučuje o pojedinačnim subjektivnim pravima.

\section{LITERATURA}

1. Crnković, Mateja. „Koncepcije o prirodi upravnog spora u hrvatskom i poredbenom pravu“. Zbornik Pravnog fakulteta u Zagrebu 65, br. 5 (2015): 693-791.

2. Hrvatska enciklopedija, Leksikografski zavod Miroslav Krleža. Pristup 23. prosinca 2020., https://www.enciklopedija.hr/natuknica.aspx?ID=33163

3. Ljubanović, Boris i Bosiljka Britvić Vetma. „Vrste upravnih sporova“. Hrvatska $i$ komparativna javna uprava: časopis za teoriju i praksu javne uprave 11, br. 3 (2011): 753-772.

4. Odluka o izmjenama i dopunama Prostornog plana Osječko-baranjske županije Županijski glasnik, br. $4 / 10$.

5. Odluka o izmjeni i dopuni Odluke o komunalnom redu Službeni glasnik Grada Dubrovnika, br. 8/19.

6. Odluka o komunalnom doprinosu Grada Crikvenice Službene novine Primorsko-goranske županije, br. 45/09. 11/11., 14/11. i 17/13.

7. Odluka o kriterijima za sufinanciranje smještaja djece u predškolskim ustanovama u ostalim gradovima i općinama Primorsko-goranske županije te obrtima za obavljanje djelatnosti predškolskog odgoja i obrtima s registriranom djelatnošću dadilje na području Primorsko-goranske županije, Službene novine Primorsko-goranske županije, br. 13/16.

8. Odluka o novčanoj pomoći po rođenju djeteta, Službene novine Primorsko-goranske županije, br. 28/12. i 36/12.

9. Odluka o postavljanju reklamnih panoa, Službeni glasnik Grada Nina, br. 29/07. i 4/09.

10. Odluka o utvrđivanju statusa javnog dobra u općoj upotrebi - k.č.zgr. 115 i k.č.zgr. 116, obje k.o. Pula, Službene novine Grada Pule, broj 6/16.

11. Omejec, Jasna i Slavica, Banić. „Diferencijacija propisa i općih akata u budućoj praksi Ustavnog suda i upravnog suda u povodu Zakona o upravnim sporovima (2010.)“. Zbornik radova Pravnog fakulteta u Splitu 49, br. 2 (2012): 309-324.

12. Pravila o uravnoteženju elektroenergetskog sustava, Narodne novine, br. 133/06. i 135/11.

13. Pravilnik o mjerilima za izračun naknade za korištenje DTK-e u vlasništvu Općine Dugopolje i o mjerilima za izračun naknade za korištenje zemljišta, javnih površina i nerazvrstanih cesta koje su vlasništvo Općine Dugopolje i nad kojima upravlja Općina Dugopolje u svrhu polaganja DTK, Službeni vjesnik Općine Dugopolje, br. 5/11.

14. Šikić, Marko i Dario Đerđa. Komentar Zakona o upravnim sporovima. Zagreb: Novi informator, 2012.

15. Upravni sud u Rijeci, UsI-1283/16-5 od 15. svibnja 2018.

16. Upravni sud u Rijeci, UsI-1416/15-6 od 10. svibnja 2017. 
17. Upravni sud u Rijeci, UsI-1512/17 od 29. lipnja 2018.

18. Upravni sud u Rijeci, UsI-1543/17-3 od 20. prosinca 2017.

19. Upravni sud u Rijeci, UsI-1823/12-8 od 30. travnja 2013.

20. Upravni sud u Rijeci, UsI-40/19-9 od 8. siječnja 2019.

21. Upravni sud u Rijeci, UsI-737/15-12 od 30. lipnja 2015.

22. Upravni sud u Splitu, UsI-114/19-5 od 9. svibnja 2019.

23. Upravni sud u Zagrebu, UsI- 467/17-20 od 24. svibnja 2017.

24. Upravni sud u Zagrebu, UsI-4457/13 od 8. lipnja 2016.

25. Ustavni sud, U-III-1673/2015 od 25. svibnja 2017.

26. Ustavni sud, U-III-2522/2017 od 21. rujna 2017.

27. Ustavni sud, U-III-4035/2013 i U-III-2272/2015 od 26. siječnja 2016.

28. Ustavni sud, U-III-4397/2018 od 29.travnja 2021.

29. Ustavni sud, U-III-6013/2012 od 1. prosinca 2014.

30. Visoki upravni sud, Usoz-10/17-5 od 30. svibnja 2017., Narodne novine, br. 71/17.

31. Visoki upravni sud, Usoz-112/16-7 od 30. ožujka 2017.

32. Visoki upravni sud, Usoz-134/15 od 30. studenoga 2015.

33. Visoki upravni sud, Usoz-22/20-6 od 21. prosinca 2020., Narodne novine, br. 10/21.

34. Visoki upravni sud, Usoz-294/13-7 od 27. travnja 2015.

35. Visoki upravni sud, Usoz-341/13-7 od 26. studenoga 2014.

36. Visoki upravni sud, Usoz-44/18-4 od 29. studenoga 2018., Narodne novine, br. 120/18.

37. Visoki upravni sud, Usoz-6/14-3 od 22. prosinca 2014.

38. Visoki upravni sud, Usoz-63/17-5 od 26. rujna 2017.

39. Visoki upravni sud, Usoz-70/16-2 od 24. siječnja 2017.

40. Visoki upravni sud, Usoz-77/19-11 od 29. lipnja 2020., Narodne novine, br. 98/20.

41. Visoki upravni sud, Usoz-95/16-3 od 28. listopada 2016. (Narodne novine, br. 109/16.)

42. Visoki upravni sud, Usž-1179/15-2 od 27. travnja 2017.

43. Visoki upravni sud, Usž-1523/16-4 od 8. prosinca 2016.

44. Visoki upravni sud, Usž-2490/19-2 od 10. prosinca 2020.

45. Visoki upravni sud, Usž-2734/20-3 od 23. listopada 2020.

46. Visoki upravni sud, Usž-3545/18-3 od 19. prosinca 2019.

47. Visoki upravni sud, Usž-4103/19-2 od 12. veljače 2020.

48. Visoki upravni sud, Usž-4740/18-2 od 18. travnja 2019.

49. Zakon o općem upravnom postupku, Narodne novine, br. 47/09.

50. Zakon o upravnim sporovima, Narodne novine, br. 20/10., 143/12., 152/14., 94/16. odluka Ustavnog suda RH i 29/17. 


\section{Inga Vezmar Barlek*}

Summary

\section{THE CORRELATION BETWEEN SUBJECTIVE AND OBJECTIVE ADMINISTRATIVE DISPUTE}

This paper analyses the correlation between subjective and objective administrative dispute on the basis of case law. Although the aims of both administrative disputes are different, case law shows that the two disputes are connected and interdependent. The author instructs about the different objections which are allowed in both disputes and exposes about legal consequences of abolishment of general act towards specific subjective positions. The author points out the role of all courts to submit the request to the High Administrative Court of the Republic of Croatia if there is a suspicion about the legality of general act applicable in the concrete case pending before a specific court.

Keywords: subjective dispute; objective dispute; purpose of the dispute; diversity; interdependence.

* Inga Vezmar Barlek, mr. sc., Judge of High Administrative Court of the Republic of Croatia; Inga.Vezmar@vusrh.pravosudje.hr. ORCID: https://orcid.org/0000-0003-1313-2849. 
